\title{
Knowledge and perceptions of haemoglobinopathy carrier screening among general practitioners in Cardiff
}

\author{
DARREN SHICKLE AND ALISON MAY \\ From the Department of Haematology, University of Wales College of Medicine, Heath Park, Cardiff CF4 \\ $4 X N$.
}

SUMmARY A questionnaire was sent to 164 principal general practitioners working in Cardiff. A response rate of $81 \%$ was achieved. A total of $70 \%$ of respondents had had professional contact with a carrier for thalassaemia and a similar number for sickle cell disease, while $57 \%$ had recommended that a patient should be screened for haemoglobinopathy status. GPs tended to underestimate greatly the prevalence of haemoglobinopathies in South Glamorgan, and were uncertain of the ethnic minorities that were at particular risk. A carrier screening programme was considered justified by the majority of GPs in Cardiff and reasons for this opinion were examined. However, before a screening programme is started, information on whom to screen and their relative risk needs to be made more widely available.

A local haemoglobinopathy carrier screening programme requires a coordinated approach by all health professionals involved, with each person having a reasonable level of accurate information to supply to patients. In particular the programme relies on the support and understanding of general practitioners to whom people will turn for advice and who may become increasingly responsible for initiating or carrying out these tests.

It is important for GPs to be aware of the communities at particularly high risk of haemoglobinopathy and of the prevalence within the population, so that they can provide appropriate, targetted information.

The haemoglobinopathy carrier prevalence in South Glamorgan is at least $1.3 \%{ }^{1}$ As part of our research on haemoglobinopathy carrier screening in South Glamorgan, we investigated local general practitioners' awareness of the haemoglobinopathies, their previous exposure to haemoglobinopathy carriers, and the degree of support they would give to a haemoglobinopathy carrier screening programme.

\section{Methods}

Questionnaires (see appendix) were sent by post to

Received for publication 12 April 1988

Revised version accepted for publication 19 July 1988. all 164 principal GPs working within the city of Cardiff (listed by the Family Practitioner Committee) and returned in the stamped addressed envelope provided. Doctors who did not respond within four weeks were sent a second questionnaire.

In order to test for an association between correct knowledge about groups at risk and support for a local haemoglobinopathy carrier screening programme, the answers to question 5 were scored: +1 for a correct answer ("yes" for all countries except for Germany and Poland), 0 for "don't know" or no response, and -1 for an incorrect answer. A high score group $(+6$ to +10$)$, a moderate score group $(+1$ to +5$)$, and a low score group $(<0$ to 0$)$ were thus defined.

Probability of obtaining results by chance (p) was measured using a $\chi^{2}$ test.

\section{Results}

A questionnaire was returned by $132(81 \%)$ of 164 general practitioners (106 after the first approach, while 26 completed the second questionnaire sent).

Ninety-two $(70 \%)$ GPs had come into contact with a carrier for thalassaemia, $93(70 \%)$ had encountered a carrier for sickle cell disease, and 77 $(58 \%)$ had had experience of both. Seventy-five $(57 \%)$ GPs had suggested to a patient that they should be screened for haemoglobinopathy carrier status in the last five years. 
Fig 1 shows the GPs' estimates of the haemoglobinopathy carrier rate among all women of reproductive age in South Glamorgan, selected from six options in the questionnaire. Fewer than $10 \%$ of GPs selected $1 \%$, the option that is nearest to the true prevalence; $14 \%$ of respondents did not answer this question, some admitting that they had "no idea".

In response to question 4, the GPs' ranking of the incidence of births of the carriers of the most prevalent genetic disorders was fairly accurate except for a considerable underestimate of the relative incidence of the carrier state for phenylketonuria (table 1).

Table 2 shows the GPs' ideas of whether they should screen people originating from 10 named countries for which the estimated actual $\beta$ chain abnormality carrier rates are known. ${ }^{3}$ There was

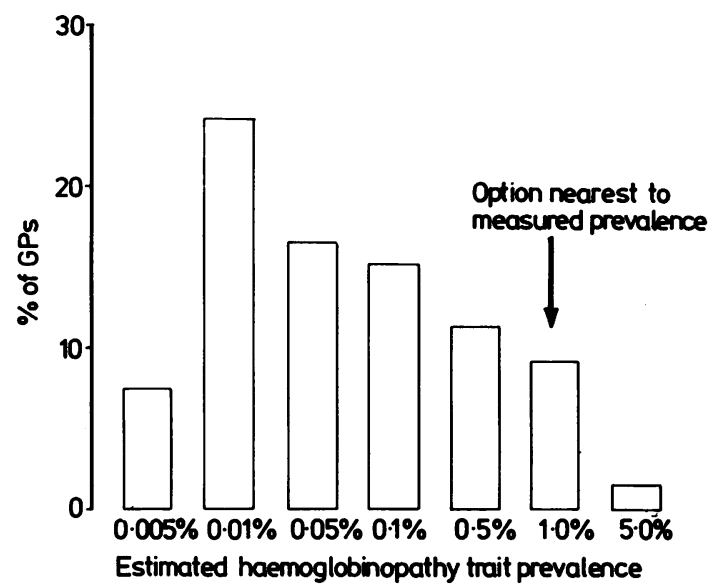

FIGURE "What do you estimate the haemoglobinopathy carrier rate to be among all women of reproductive age in South Glamorgan?"' (87\% response to question).

TABLE 1 The ranking by GPs of the birth incidence in South Glamorgan of the carriers of the most prevalent genetic disorders.

\begin{tabular}{lclc}
\hline Disorder & $\begin{array}{l}\text { Approx carrier } \\
\text { frequency/1000 births }\end{array}$ & $\begin{array}{l}\text { Actual } \\
\text { rank }\end{array}$ & $\begin{array}{l}\text { GPs' } \\
\text { ranking }\end{array}$ \\
\hline Cystic fibrosis & $45^{*}$ & 1 & 1 \\
Phenylketonuria & $20^{*}$ & 2 & 5 \\
Haemoglobinopathy & $>13 \dagger$ & 3 & 2 \\
Muscular dystrophy & $<1^{*}$ & $4 / 5$ & 4 \\
Haemophilia & $<1^{*}$ & $4 / 5$ & 3 \\
\hline
\end{tabular}

*Calculated from figures given in reference 2 for affected homozygotes or hemizygotes.

tSee reference 1 .
TABLE 2 "Do you think that a person whose family originates from one of the following countries is at risk of being a haemoglobinopathy carrier and hence should be screened?"

\begin{tabular}{|c|c|c|c|c|}
\hline & $\begin{array}{l}\text { Yes } \\
(\%)\end{array}$ & $\begin{array}{l}\text { No } \\
(\%)\end{array}$ & $\begin{array}{l}\text { Don't } \\
\text { know } \\
(\%)\end{array}$ & $\begin{array}{l}\% \text { of population } \\
\text { carriers for } \beta \\
\text { chain defects }\end{array}$ \\
\hline Brazil & 39 & 41 & 21 & 4 \\
\hline Germany & 1 & 79 & 21 & - \\
\hline Greece & 77 & 12 & 12 & 8 \\
\hline India & 51 & 31 & 18 & 4 \\
\hline Iraq & 61 & 20 & 19 & 6 \\
\hline Italy & 63 & 19 & 18 & 4 \\
\hline Nigeria & 82 & 9 & 8 & 28 \\
\hline Pakistan & 55 & 28 & 17 & 6 \\
\hline Poland & 2 & 77 & 21 & - \\
\hline Thailand & 57 & 35 & 8 & 26 \\
\hline
\end{tabular}

TABLE 3 "Do you think a screening programme for haemoglobinopathy traits in South Glamorgan is justified?" (10 did not respond.)

\begin{tabular}{|c|c|c|}
\hline & Yes & No \\
\hline $\begin{array}{l}\text { No of respondents } \\
\text { "What are your reasons for this opinion }\end{array}$ & 76 & 46 \\
\hline Ethical reasons & 21 & 1 \\
\hline Cost efficiency & 10 & 29 \\
\hline Incidence rate & 26 & 27 \\
\hline Relative cost benefit & 19 & 26 \\
\hline Seriousness of condition & 60 & 3 \\
\hline
\end{tabular}

much confusion about which are 'high risk' countries $\overrightarrow{\overrightarrow{0}}$ and a high percentage of "don't know" answers.

A total of $58 \%$ of the respondents $(46 \%$ of all GPs) thought that a carrier screening programme was justified and the reasons given are shown in table 3. Factors associated with this support were examined. There was a positive association with having already recommended screening $(\mathrm{p}<0.05)$ and with correct knowledge of groups at risk $(p<0.02)$. There was no clear relation with previous experience of haemoglobinopathy carriers nor with correct knowledge of incidence, though GPs who $\frac{7}{0}$ did not support screening on the grounds of low incidence had tended to choose the lower option for $N$ carrier rate (five chose $0.005 \%$ and only three $\mathrm{N}$ thought that the prevalence was more than $0.01 \%$, N while six said “don't know”).

\section{Discussion}

A WHO Working Group identified "general $\stackrel{\infty}{?}$ ignorance about genetic problems among health $\frac{T}{\circ}$ workers" as a major limitation in the delivery of a haemoglobinopathy prevention service and re- $\frac{?}{1}$ commended "an intensive information campaign 2 targetted at the relevant groups in the medical pro- - 
fession". ${ }^{3}$ More recently, in the UK, a King's Fund Forum Consensus statement on screening for fetal and genetic abnormality ${ }^{4}$ commented that "basic education in modern genetics is deficient in the curriculum of medical students and other health professionals, and should be remedied in basic and postbasic training". The authors are not aware of other studies of the level of awareness of haemoglobinopathies among general practitioners in the UK. This study indicates some important deficiencies in knowledge.

When asked to estimate haemoglobinopathy prevalence, $37 \%$ of repondents were within a factor of 10 of the correct answer (that is, chose an option of $0.1 \%$ or more). The prevalence of the $\beta$ thalassaemia gene within the indigenous British population is commonly quoted as more than $0.1 \%$ ( 1 in $1000),{ }^{5}$ yet nearly half of the respondents made an estimate below this level. The many "don't know" responses indicate that many doctors felt that they did not have enough information even to make an 'educated guess'.

Despite the underestimate of haemoglobinopathy prevalence in South Glamorgan, the GPs ranked them fairly high compared with other genetic disorders. Of the five disorders listed in table 1 routine screening is performed in South Glamorgan only for phenylketonuria, yet this was ranked bottom by GPs. This probably indicates a general lack of awareness about genetic disorders, not just the haemoglobinopathies.

It is important for health professionals to be aware of the haemoglobinopathy prevalence in the populations from the Indian subcontinent, the Caribbean and Africa, and the Mediterranean area that form most of the ethnic minorities in the UK. This study showed considerable uncertainty and some mistaken impressions among GPs. Only half of the respondents would screen a person originating from India or Pakistan, two-thirds would screen a person originating from Italy, while about threequarters would screen someone originating from Nigeria or Greece.

About half the GPs in Cardiff favour a local haemoglobinopathy carrier screening programme. The principle reasons for the lack of support were perceived as cost/efficiency, incidence, and cost/ benefit. Although it is intrinsically difficult to measure all the components of the equations required in cost/efficiency and cost/benefit analysis, where this has been attempted haemoglobinopathy carrier screening has been shown to be cost effective. ${ }^{2}$ Most of those who thought screening was not justified had underestimated haemoglobinopathy prevalence in the area. It is necessary to provide GPs with accurate information on these issues.

The large proportion of GPs who have encountered haemoglobinopathy carriers indicates the need to provide information to all doctors and not just those who work in districts with large ethnic minority communities.

This study showed that GPs with better knowledge of communities at risk and prevalence are more likely to support screening. Therefore, it seems likely that, with better information, a haemoglobinopathy screening programme in this area would have the support of most GPs. An American study ${ }^{6}$ found that the compliance rate for Tay-Sachs disease carrier screening was highest with well informed and motivated advocates. A more enthusiastic involvement in the screening programme should result in a more effective and efficient service.

We thank Dr Peter Lewis, Dr Simon Smail, and the Department of General Practice (UWCM) for their advice and assistance. DS was in receipt of funding from the Medical Research Council, Sir Cennydd Traherne Scholarship, British Medical Student's Trust, and the Blood Research Fund.

\section{References}

${ }^{1}$ Bentley DP, Cavill I, Choiseul M, et al. Haemoglobinopathy screening in a 'low risk' area of the United Kingdom: South Glamorgan, Wales. Acta Haematologica (Basel) 1987;78:149-53.

2 Weatherall DJ. The new genetics and clinical practice. Oxford: Oxford University Press, 1985.

${ }^{3}$ World Health Organisation. Update of the progress of haemoglobinopathies control. Report of the Third and Fourth Annual Meetings of the WHO Working Group on the Community Control of Hereditary Anaemias. Unpublished WHO document, 1985, HMG/WG/85.8.

${ }^{4}$ King's Fund Forum consensus statement: screening for fetal and genetic abnormality. $\mathrm{Br}$ Med $J$ 1987;295:1551-3.

5 Modell B, Ward RHT, Fairwater DVI. Effect of introducing antenatal diagnosis on reproductive behaviour of families at risk for thalassaemia major. Br Med J 1980;280:1347-50.

${ }^{6}$ Beck E, Blaichman S, Scriver CR, et al. Advocacy and compliance in genetic screening behaviour of physicians and clients in a voluntary program of testing for the Tay-Sachs gene. $N$ Engl J Med 1974;291:1166-70.

Correspondence to Dr A May, Department of Haematology, University of Wales College of Medicine, Heath Park, Cardiff CF4 4XN. 
APPEN DIX Questionnaire.

(1) Have you professionally come into contact with a carrier for: Thalassaemia? Yes ( ) No ( ) Sickle cell disease? Yes ( ) No ( )

(2) Have you suggested to a patient that he/she should be screened as a carrier for a haemoglobinopathy within the last five years? Yes ( ) No ( )

(3) What do you estimate the haemoglobinopathy carrier rate to be among $A L L$ women of reproductive age in South Glamorgan? (Please circle one answer only.)

(4) Of which of the following disorders are there likely to be most carriers born in South Glamorgan during 1987? (Please rank in order of incidence: $1=$ most common, $5=$ least common, etc.)

$\begin{array}{ll}\text { Cystic fibrosis } & (\text { ) } \\ \text { Haemoglobinopathies } & (\text { ) } \\ \text { Haemophilia } & ()^{2} \\ \text { Muscular dystrophy } & \text { ( ) } \\ \text { Phenylketonuria } & \text { ( ) }\end{array}$

(5) Do you think a person whose family originates from one of the following countries is at risk of being a carrier and hence should be screened?

$\begin{array}{lc}\text { Brazil } & \text { Yes ( ) } \\ \text { Germany } & \text { Yes ( ) } \\ \text { Greece } & \text { Yes ( ) } \\ \text { India } & \text { Yes ( ) } \\ \text { Iraq } & \text { Yes ( ) } \\ \text { Italy } & \text { Yes ( ) } \\ \text { Nigeria } & \text { Yes ( ) } \\ \text { Pakistan } & \text { Yes ( ) } \\ \text { Poland } & \text { Yes ( ) } \\ \text { Thailand } & \text { Yes ( ) }\end{array}$

No ( )
No ( )
No ()
No ()
No ()
No ()
No ()
No ()
No ()
No ()

(6) Do you think a screening programme for haemoglobinopathy traits in South Glamorgan is justified?

$$
\text { Yes ( ) No ( ) }
$$

(7) What are your reasons for this opinion? Because of: (you may tick more than one)

Ethical reasons

Cost efficiency

Incidence rate

Relative cost benefit

Seriousness of condition

Other (please state) 